\title{
Using Soil Erosion as an Indicator for Integrated Water Resources Management: A Case Study of Ruiru Drinking Water Reservoir, Kenya
}

Ann W. Kamamia ( $\square$ ann.kamamia@mailbox.tu-dresden.de )

Technische Universität Dresden https://orcid.org/0000-0002-7228-4175

\section{Cordula Vogel}

Technische Universität Dresden

Hosea M. Mwangi

Jomo Kenyatta University of Agriculture and Technology

Karl-heinz Feger

Technische Universität Dresden

Joseph Sang

Jomo Kenyatta University of Agriculture and Technology

Stefan Julich

Technische Universität Dresden

\section{Research Article}

Keywords: erosion, soil-water nexus, digital soil mapping, spatio-temporal dynamics, RUSLE, erodibility

Posted Date: August 6th, 2021

DOI: https://doi.org/10.21203/rs.3.rs-765385/v1

License: (1) This work is licensed under a Creative Commons Attribution 4.0 International License.

Read Full License 


\section{Abstract}

Functions and services provided by soils play an important role for numerous Sustainable Development Goals (SDGs) involving mainly food supply and environmental health. In many regions of the earth, water erosion is a major threat to soil functions and is mostly related to land use change or poor agricultural management. Selecting proper soil management practice, requires site-specific indicators such as water erosion, which follow a spatio-temporal variation. In this study, the Revised Universal Soil Loss EquationRUSLE-complemented with the cubist-kriging interpolation method was applied to develop monthly soil erosion risk maps for the data-scarce catchment of the Ruiru drinking water reservoir located in Kenya. An erodibility map created with digital soil mapping methods $\left(R^{2}=0.63\right)$ revealed that $46 \%$ of the soils in the catchment have medium to high erodibility. The monthly erosion rates showed two distinct potential peaks of soil loss over the course of the year, which are consistent with the bimodal rainy season experienced in central Kenya. A higher soil loss of $2.24 \mathrm{t} /$ ha was estimated for long rains (March- May) as compared to $1.68 \mathrm{t}$ /ha for short rains (October-December). Bare land and cropland are the major contributors to soil loss. Furthermore, the spatial maps reveal that areas around the indigenous forest on the western and southern parts of the catchment have the highest erosion risk. In conclusion, erosion risk maps can be decisive for developing spatially explicit, efficient and timely soil management strategies thus allowing continued multi-functional use of land within the soil-water-food nexus.

\subsection{Introduction}

Soils form a critical component influencing the hydrological cycle and are crucial in supporting and protecting food and energy production. The sustainable development goals (SDGs) linked to soils include: No poverty SDG 1, zero hunger SDG 2, good health and well-being SDG 3, clean water and sanitation SDG 6, affordable and clean energy SDG 7, sustainable cities and communities SDG 11, climate change SDG 13 (United Nations 2015). Soil health must therefore be maintained in order to sustain the services they provide especially within the water-energy-food nexus (Lal et al. 2017). However, the ability of soils to sustainably undertake their functions is under threat due to soil degradation majorly through accelerated water erosion. Most soils today can be regarded as being in a state of fair, poor or very poor condition (Montanarella et al. 2015). This is due to the harmful impacts of anthropogenic activities such as deforestation, overgrazing, intensive tillage on steep terrain, over-cropping and poor soil management practices (Borrelli et al. 2017; Ebabu et al. 2019; Rientjes et al. 2011). While the onsite effects of erosion include land degradation and loss of fertility (Haregeweyn et al. 2017; Kidane et al. 2019; Lambin et al. 2003), off-site effects include siltation, sedimentation, eutrophication of water bodies and even induced flooding (Borrelli et al. 2017; Ozsoy et al. 2012). Borrelli et al. (2017) rated African countries around the equator as erosion hotspots. Due to high population growth compounded by an agriculture-based economy, existing forests are subjected to increasing pressure. This has resulted in deforestation to pave way for other competing land-uses such as settlement and agriculture (Carr 2004; Mulinge et al. 2016). Deforestation coupled with high rainfall and fragile terrains with exposed soils has resulted in severe soil erosion. Maloi et al. (2016) showed that a shift in land use, primarily from forests 
to cultivation, has increased siltation in the Ruiru Reservoir, thereby decreasing its storage capacity by $11-14 \%$ in 65 years. An assessment of the soil erosion risks can assist in watershed assessment in areas where erosion is a major threat (Patil 2018). However, the processes involved in soil loss by water underlie a spatiotemporal variability (Patil 2018), and therefore should be taken into account for proper integrated water resource management- IWRM-. IWRM refers to "a process which promotes the coordinated development and management of water, land and land related resources, in order to maximize the resultant economic and social welfare in an equitable manner" (GWP 2000). This denotes that water and land/soil are interrelated (Calder 2006). Water problems such as water quality and quantity cannot be treated in isolation and a "system thinking approach" between the water-soil nexus should be adopted. Using average erosion soil rates that are highly variable in space and time or even across areas can camouflage erosion occurring at smaller scales (Hatfield et al. 2017). Furthermore, extreme events in precipitation as a result of climate change have increased the potential for soil erosion in ways that are not well understood and assessed. Hence, proper spatio-temporal analysis could provide a better understanding of the climate variability and soil ecosystem services intersection. With such information, decision-makers and land resource managers can develop more timely and targeted cost-effective IWRM.

Different studies have been undertaken to quantify soil erosion. The most accurate and ideal methods involve conducting field experiments using erosion plots. Here, erosion measurements are carried out under natural conditions (Ampofo et al. 2002; Boardman and Evans 2020). Alternatively, the rain events can be simulated, where parameters such as rainfall intensity, drop size, spatial variability can be adjusted (Duiker et al. 2001; Stroosnijder 2005; Ries et al. 2013; Iserloh et al. 2013). Other methods include the use of radionuclide tracers (Maina et al. 2018; Khodadadi et al. 2019). Nevertheless, direct erosion measurements are expensive, unstandardised, time-consuming and limited in terms of spatial and temporal variation (Lal 2001; Stroosnijder 2005; Ries et al. 2013; Dutta 2016). The setbacks faced by direct measurements have resulted in the use of models to predict soil erosion. These models are primarily classified into three (physical, conceptual and empirical) depending on model input and the extent of the theoretical principles applied in the model (Igwe et al. 2017; Patil 2018). Physical models take the individual components affecting soil erosion into account, e.g. their complex interaction as well as spatial and temporal variability (Igwe et al. 2017; Patil 2018). Such models include the European Soil Erosion Model-EUROSEM (Morgan et al. 1998). Conceptual models like the Soil and Water Integrated Model-SWIM-(Krysanova et al. 1998) represent processes in terms of fluxes at different spatial and temporal resolutions. Empirical models are the least data-intense and focus primarily on observed data and their responses. These include the Universal Soil Loss Equation-USLE-(Wischmeier and Smith 1978) and its revised version, the Revised Universal Soil Loss Equation-RUSLE-(Renard et al. 2017), which are conventionally applied to quantify long-term average soil loss (Alewell et al. 2019). They are used to calculate the annual erosion rate given in $\mathrm{t} / \mathrm{ha} / \mathrm{yr}$. This loss depends on the erosion risk factors, which include rainfall erosivity (R-factor), soil erodibility (K-factor), slope steepness and length (LSfactor), cover management ( $\mathrm{C}$-factor) and support practices (P-factor). The R-factor highly correlates with rainfall amount and intensity (Schmidt et al. 2016). Hence, it is expected that there will be an inter-annual and seasonal variation of this factor wherefrom dynamic soil erosion risks can be identified. Recent 
studies on the temporal variability of the R-factor revealed a distinct seasonality influenced by intense rainfall events in Switzerland (Schmidt et al. 2016). The K-factor, defined as soil loss rate per erosion index, expresses the susceptibility of a soil to be detached and transported by rainfall and runoff (Renard et al. 2017). Direct measurements of this factor require long-term soil erosion studies or the use of soil property data (Wischmeier and Smith 1958). There exists a soil erodibility dataset at higher resolution (up to $500 \mathrm{~m}$ ) for some developed regions such as Europe (Panagos et al. 2014). But only coarse estimates are available for Africa (Borrelli et al. 2017). Since the K-factor is considered a significant parameter in the soil erosion process, its spatial variability across different landscapes should be considered (Zhu et al. 2010). The spatial variability of the K-factor has been mapped through interpolation methods (Addis and Klik 2015; Avalos et al. 2018) and machine learning algorithms such as the cubist method (Panagos et al. 2014). The LS-factor accounts for the effects of slope steepness and length on erosion (Alexandridis et al. 2015). The $\mathrm{C}$-factor represents the effect of plants as well as soil cover, biomass and disturbing activities on erosion. Schmidt et al. (2018) identified crop cover as one of the main triggers of soil erosion as it is highly dependent on their seasonal dynamics and growth curve. The P-factor includes erosion control measures such as contour cropping, terracing, grass strips and all other enhancements that reduce slope length, thereby reducing the amount and rate at which the soil is lost (Renard et al. 2017).

The RUSLE has been reported to generate quantitative estimates of soil loss in ungauged catchments that have been applied in designing sound conservation measures (Asis and Omasa 2007). Moreover, recent applications of soil loss models such as RUSLE have been complemented by the application of GIS and remote sensing technologies. Such technologies include the use of satellite images and geospatial algorithms such as Interpolation Distance Weighing-IDW-(Angulo-Martínez et al. 2009; Gaubi et al. 2017), kriging (Wang et al. 2002; Kouli et al. 2009), regression equations (Panagos et al. 2014) and machine learning available through Digital Soil Mapping-DSM-(Avalos et al. 2018; Taghizadeh-Mehrjardi et al. 2019). Jenny (1941) established that soil physical and chemical properties are influenced by five soil-forming factors of climate, organisms, topography, parent material and time. This relationship can be exploited with DSM. DSM assumes that a relationship exists between environmental conditions and soil properties (McBratney et al. 2003). By using prediction algorithms, a suite of environmental covariates and measured soil properties, this relationship can be obtained and extended to areas without observations. This means that soil properties such as soil erodibility can be mapped at much lower costs and effort. With access to both geospatial algorithms and higher quality input data, models such as RUSLE can be applied at higher temporal and spatial scales (Kouli et al. 2009; Ganasri and Ramesh 2016; Uddin et al., 2016; Dragičević et al. 2018; Schmidt et al. 2019; Wang et al. 2019). Schmidt et al. (2016) demonstrated that it is possible to predict soil loss dynamics by modelling the intra-annual variability of the R-factor and C-factor within the RUSLE. By applying the RUSLE equation on Swiss grassland with a sub-annual resolution at a national scale, the authors showed that the mean monthly soil loss by water was 48 times higher in summer as compared to winter. However, the effectiveness of the application of RUSLE depends on the availability of datasets. For developing countries, global datasets are sometimes the only data available. Although providing valuable data, this may still be considered too coarse for effective application. But by undertaking purposive soil sampling 
and applying digital soil mapping, time and spatial variability of soil properties and vulnerabilities can effectively be determined in data-scarce areas (Kamamia et al. 2021).

In the presented study, we applied a combination of DSM with the RUSLE method for a data-scarce watershed in Kenya, East Africa. We additionally compared the predict monthly soil loss with available global soil loss averages. With the application of the temporally and spatially variable RUSLE prediction, we want to address the following questions. 1) What is the impact of rainy periods on erosion and soil loss in the Ruiru Reservoir catchment? 2.) What is the contribution of each of the different LULC classes to erosion in the catchment? 3.) Can the spatio-dynamic erosion assessment be an effective tool in influencing the allocation of soil erosion mitigation measures?

\subsection{Materials And Methods}

\subsection{Ruiru reservoir catchment}

The Ruiru reservoir catchment (Fig. 1) is located in Kiambu County, Kenya. The catchment covers 51 km² $^{2}$ from the uplands close to the Rift Valley escarpments to the Ruiru Reservoir at the catchment's outlet. A humid highland subtropical climate with wet and dry seasons characterises the local climate. An average annual rainfall of $1300-1500 \mathrm{~mm}$ is received in the catchment. The long rains are experienced between March and May, while the short rains are experienced between October and December. Temperatures range between 13.0 and $24.9^{\circ} \mathrm{C}$. Temperatures are highest from January to March and lowest in July to August (Nyakundi et al. 2017). Nitisols are the dominating soils in the catchment, whereas a small portion of Andosols can be found in the upper part of the catchment (Fig. 1). These soils are influenced by pyroclastic and igneous volcanic geology. The region belongs to the tea-dairy zone and subsistence farming is characterised by low-input low-output production (Kamamia et al. 2021). The Ruiru Reservoir in which the Ruiru River drains, located in the lowest part of the catchment, was designed to supply $23,000 \mathrm{~m}^{3} /$ day of water to the residents of Nairobi, the capital city of Kenya. Maloi et al. (2016) reported that land-use change, majorly from forest to agriculture, has increased sediments in runoff into the reservoir especially during the rainy seasons thus increasing the treatment costs. Hence, land use management must address the water insecurities in the catchment to ensure sustainable supply of good quality water (Calder 2006)

\subsection{Determining the location of the soil sampling sites}

A 30 m sink-filled Digital Elevation Model (DEM) downloaded from the Earth Explorer hosted by the United States Geological Survey was used (Earth Explorer-USGS 2019) to extract derivatives using the System for Automated Geoscientific Analyses-SAGA-GIS (Conrad et al. 2015). From the DEM, slope, aspect, plan curvature, profile curvature, relief, elevation, Topographic Wetness Index-TWI and hill shading derivatives were extracted. Additional data acquired include 1.) Soil map at scale 1:250000 from the Soil and Terrain-SOTER-database of the International Soil Reference and Information CentreISCRIC- (Batjes 2002). 2.) Coarse geology map from the Survey of Kenya-SOK. 
All DEM derivatives, and the additional maps obtained were stacked together and split into 30-m segments in ArcGIS (ArcMap version 10.2). This means that each segment was represented by a series of a different set of covariates which included the DEM derivatives, the geology, soil and land use values. The sampling distribution was determined by using the conditioned Latin hypercube sampling-cLHSalgorithm (Minasny and McBratney 2006) included in the $c L H S$ package (Roudier et al. 2012) of the $\mathrm{R}$ statistical software, version 3.5.1 (R Core Team 2019). 90 soil sampling sites were selected for this study. Similarity sites within a 500-m radius for each site were determined. These were set as alternative sampling sites to the originally selected sampling sites. For example, the sites would act as substitute sites where permission to access private land was not granted or where accessibility was constrained due to geographical barriers or safety reasons.

\subsection{Fieldwork}

The soil sampling sites were located in the field with the aid of a GPS. Caution was exercised to ensure that samples were collected from the exact coordinates obtained from the selection process. At each site, undisturbed soil samples from the top $0-30 \mathrm{~cm}$ were collected by using soil cores for the determination of bulk density, texture and organic carbon content.

\subsection{Determination of soil parameters in the laboratory}

Soil texture was determined in the laboratory of the Institute of Soil Science and Site Ecology, TU Dresden by using the wet sieving and sedimentation method. The sand fraction was determined using wet sieving, while the silt and clay fractions were determined using sedimentation analysis. This was done using the Sedimat 4-12 equipment (Umwelt-Geräte-Technik-UGT-GmbH, Müncheberg, Germany). The organic carbon content $\left(\mathrm{C}_{\text {org }}\right)$ was determined by dry combustion using the Vario TOC Cube Elementar equipment (Elementar Analysensysteme GmbH, Langenselbold, Germany).

\subsection{Analysis}

\subsection{Supervised Classification of the major land-uses in the Ruiru catchment}

A Landsat 8 image Operational Land Imager- OLI-for August was downloaded from the Earth explorer (EarthExplorer-USGS 2019) using the semi-automatic classification plugin in QGIS 3.4 (QGIS.org 2019). All the bands were then clipped to the study area size and converted to reflectance (Young et al. 2017). A band set with band5, band4 and band3 (Bands 5-4-3), which represents a temporary virtual raster that allows for the display of composite colours, was created (NASA 2013). Next, the training sites were defined by creating regions of interest-ROI. In addition to georeferenced points obtained during the field campaign, Google Earth was used to increase the number of ROIs. The main defined land-use classes were water-WTR, Bare land-BARE, Cropland-AG, Grassland and Shrubland-GR/SH, Built-upBLD and Forests-FOR. The cropland land-use was further split into the mixed cropland-AG and TeaTEA. The classification was carried out by using the maximum likelihood algorithm-MLA (Benediktsson 
et al. 1990). The MLA is a rule-based algorithm that is based on the probability that a given pixel belongs to a particular class. This was done iteratively and with the Band 5-4-3 (see description in Table 1) band combination.

Table 1 Landsat 8 band description and combination

\begin{tabular}{|ll|}
\hline Band Number & Description \\
\hline Band 1 & Coastal \\
\hline Band 2-4 & Visible blue, green, red \\
\hline Band 5-7 & Infrared (Near, shortwave $(1.56-1.66 \mu \mathrm{m})$, shortwave $(2.10-2.30 \mu \mathrm{m})$ \\
\hline Band 8 & Panchromatic \\
\hline Band 9 & Cirrus \\
\hline Band 10-11 & Infrared (Longwave $(10-11.3 \mu \mathrm{m})$, longwave $(11.5-12.5 \mu \mathrm{m})$ \\
\hline
\end{tabular}

Source: https://landsat.gsfc.nasa.gov/landsat-8/landsat-8-bands/

Each time the classification was done, the spectral signatures (reflectance as a function of the shortwave and different objects have unique signatures which can be used for classification) (NASA 1999) were assessed. However, during classification similar spectral signatures may be recorded for different materials which could lead to misclassification (Hadi et al. 2018). To overcome this, more training sites were delineated to allow MLA to discriminate between the various vegetation cover and between bare land and built-up areas. The post-processing step included the removal of raster polygons smaller than the minimum mapping unit-MMU, which was set at 25 . As the GR/SH vegetation was limited, a new class "Natural Vegetation-NV" was created by aggregating the grasslands, shrublands and forests. A final land-use map with an accuracy of $71 \%$ obtained from the confusion matrix, was created.

\subsection{Calculating the individual RUSLE factors}

The RUSLE (Renard et al. 2017) was determined by multiplying all the erosion risk factors represented below: 
where: $A$ is the annual soil loss in $t h a^{-1} y r^{-1}$

$R$ is the rainfall erosivity (MJ $m m^{h a^{-1}} \mathrm{~h}$ year)

$K$ is the soil erodibility factor $\left(t h a^{-1} R\right.$ unit $\left.^{-1}\right)$

LS is the topographic factor (dimensionless)

$C$ is the cropping management factor (dimensionless)

$P$ is the practice support factor (dimensionless)

This equation was modified to include the temporally dynamic soil erosion factors based on (Schmidt et al. 2019) (Eq. 1)

$$
A_{\text {monthly }}=\mathrm{R}_{\text {month }} * K * L * S * C_{\text {month }} * P
$$

where $A_{\text {month }}$ is the monthly soil loss in $t$ ha ${ }^{-1}$ month $^{-1}$

The data sources and derivation for the RUSLE parameters are given in Table 2.

Table 2 Overview of the individual erosion risk factors, datasets and formula used 


\begin{tabular}{|c|c|c|}
\hline Erosion Factor & Data source & Calculation \\
\hline $\begin{array}{l}\text { Rainfall erosivity, } \\
\text { (monthly) } R_{\text {month }} \\
\text { factor }\end{array}$ & $\begin{array}{l}\text { Rainfall station } \\
\text { data }\end{array}$ & $\begin{array}{c}\qquad M F I=\frac{P i}{P} \\
\text { And } R=1.735 * \\
\text { MFI represents the Modified Fournier Equation(Tiwari et al. 2014) } \\
\text { pi is the monthly rainfall } \\
P \text { is the annual rainfall }\end{array}$ \\
\hline $\begin{array}{l}\text { Soil erodibility, K- } \\
\text { factor }\end{array}$ & $\begin{array}{l}\text { Measured soil } \\
\text { texture, soil } \\
\text { organic matter, } \\
\text { soil permeability }\end{array}$ & $\begin{array}{c}K=2.77 * 10^{-6} * M^{1.14} *(12-O M)+0.043 \\
*(A-2)+0.033 *(4-D) \\
\text { with }: \\
M=(\% \text { silt }+\% \text { fine sand }) *(\% \text { silt }+\% \text { sand }(\text { fine sand excluded })) \\
\text { OM } \% \text { Organic matter } \\
A=\text { Aggregate stability class } \\
D=\text { permeability class }\end{array}$ \\
\hline $\begin{array}{l}\text { Cover and } \\
\text { management } \\
\text { (monthly), } C_{\text {month }} \\
\text { factor }\end{array}$ & $\begin{array}{l}\text { Landsat } 8+ \\
\text { (monthly) }\end{array}$ & $\begin{array}{c}N D V I=\frac{N I R-I R}{N I R+I R} \\
\text { where NIR is the near - infrared } \\
I R \text { is the reflection in the visible spectrum } \\
C=0.1\left(\frac{-N D V I+1}{2}\right)\end{array}$ \\
\hline $\begin{array}{l}\text { Slope length and } \\
\text { Slope Steepness- LS } \\
\text { factor }\end{array}$ & $\begin{array}{l}\text { Digital Elevation } \\
\text { Model }\end{array}$ & $\begin{array}{c}L S=\left(\frac{X}{22.13}\right)^{n}\left(0.0065+0.045 s+0.0065 s^{2}\right) \\
\text { where } X \text { is slope length in meters } \\
\quad \text { is the slope gradient } \% \\
n \text { is the exponent according to the angle of slope }\end{array}$ \\
\hline
\end{tabular}

\section{R-factor}

The required rainfall data for the determination of for the years between 2011 and 2017 was obtained from the Upland Station located in the western part of the Ruiru Reservoir catchment. This is the only existing station in the catchment. These data were complemented with the gridded daily rainfall of the Climate Hazard Group Infrared Precipitation-CHIRPS (Climate Hazards Center - UC Santa Barbara 2020). 
The Modified Fournier Index-MFI- (Anoldus 1980) and consequently the factor were determined using Eq.3 (Table 2). For each month, was assumed to be spatially static. It was deemed adequate as the area of the river catchment is $51 \mathrm{~km}^{2}$ and does not experience a large monthly rainfall variation.

\section{K-factor}

Soil texture, permeability and organic matter of the topsoil obtained from the laboratory analysis were employed to determine the K-factor for the 90 sampled points using the Schwertmann (1987) method (Eq. 4). The cubist method (Quinlan 1992) with the regression kriging interpolation technique with selected covariates-Cubist-kriging - (Malone et al. 2017) presented in Table 3 was applied to create a continuous soil erodibility map.

Table 3 Covariates used in cubist-kriging

\begin{tabular}{|c|c|}
\hline Covariate Type & Description \\
\hline Terrain data & $\begin{array}{l}\text { Slope, aspect, elevation, topographic wetness index-TWI, profile curvature, plan } \\
\text { curvature, Longitudinal curvature, hill shading, catchment area, flow accumulation, } \\
\text { multiresolution ridge top flatness-MrRTF, multiresolution valley bottom flatness- } \\
\text { MrVBF, upslope length factor, }\end{array}$ \\
\hline & $\begin{array}{l}\text { Software: SAGA GIS (version 2.3.2) Requires: Sink-filled DEM } \\
\text { (https://earthexplorer.usgs.gov/) }\end{array}$ \\
\hline
\end{tabular}

Spectral data

Blue, green, red Near-Infrared, Normalised Difference Vegetation Index-NDVI

(wet-ndvid and dry season-ndviw, Green Vegetation Index-GVI

Software: ArcMap version 10.2

The cubist model divides data into partitions based on rules associated with covariates and fits a regression equation to each subset. Predictions are then determined based on the relative importance of the covariates. Moreover, three parameters must be established: rules-maximum number of partitions allowed, committees-maximum number of boosting iterations and extrapolations-model constraints (Malone et al. 2017). On the other hand, regression kriging is a spatial interpolation technique that uses a semivariogram to quantify the spatial structure of residuals (difference between the predicted and observed values) (Ma et al. 2017). In this study, soil erodibility data from the 90 sampling sites were split into two segments representing the training and testing data ( $\sim 70 \%$ and $\sim 30 \%$ respectively). First, the Cubist model was applied where the data was partitioned based on the most relevant covariates present. This represented the deterministic component of the predictions. Regression kriging, representing the stochastic component, was then undertaken. Finally, these two components were added together to arrive at the final prediction. A leave-one-out cross-validation scheme was applied to assess the accuracy of the 
predictions, which were represented using the coefficient of determination- $R^{2}$. A detailed description can be found in Malone et al. (2017).

\section{C-factor}

The monthly C-factors were adjusted based on the Normalized Difference Vegetation Index (NDVI) (Jong 1994), which was calculated from Landsat 8 images for the year 2017. The NDVI values range between 1 , for almost bare surfaces and water bodies, to 1 for densely vegetated surfaces. The NDVIs were afterwards converted to the C-factor using Eq. 4 (Almagro et al. 2019), by applying the raster calculator tool in ArcGIS (ArcMap version 10.2).

In the months where cloud cover from the Landsat 8+ was greater than 10\% (April, May, November), the Cfactor values were obtained from spline interpolation. The spline interpolation method is a minimum curvature function that passes through the data with the accuracy of their mean errors. In this method, all the data points influence the value of the interpolated point, with those closest to the main station having the greatest impact on the value of the interpolated point (Niedzielski 2015). Using the polynomials, the first and second derivatives can easily be derived, making them applicable in biological modelling such as developing plant growth curves (Quero et al. 2015).

\section{LS-factor and P- factor}

Using the DEM as an input, the LS-factor was determined by using Eq.7 in Table 2 in ArcGIS (ArcMap version 10.2). A few sporadic conservation practices were observed in the Ruiru reservoir catchment. This included 'fanya juu' terraces on steep agricultural lands and grass strips along the riparian region. To account for the 'fanya juu' terraces a threshold of $25 \%$ slope was set first for agricultural lands. This means that this conservation measure would be implemented in areas with a slope above $25 \%$. As not all farmers have adopted this conservation measure, $10 \%$ of all the possible selections were randomly selected. Using the $d p l y$ package in R statistical software version 3.5.1 (R core Team 2019), all pixels were loaded and the first filter according to the slope was implemented. The $10 \%$ of remaining pixels were selected using random sampling and a value of 0.7 was assigned according to Angima et al. (2003). Furthermore, the P-factor value for all pixels within $30 \mathrm{~m}$ of the Ruiru River was adjusted to 0.9 according to Mwangi et al. (2015) in ArcGIS (ArcMap version 10.8) to account for grass strips. These have been developed along the Ruiru River as part of an integrated water resource protection initiative by Water Rural User Association-WRUA (Kamamia et al. 2021). For all other LULC, this value was set to 1.

\section{Plausibility check with GloSEM data}

As a plausibility check, the monthly soil loss values-REG_SL- were compared with the global average soil loss estimates (GloSEM) obtained from the European Soil Data Centre- ESDAC (Borrelli et al. 2017). As presented in the flowchart (Fig. 2), the individual RUSLE factors were overlaid and multiplied with each 
other using the raster calculator tool in ArcGIS (ArcMap version 10.2). The K-factor, LS-factor and Pfactors remained static while the R-factor and $\mathrm{C}$-factor were substituted for each month. Monthly soil loss was then compared for the different LULC by using the land-use map created from Landsat 8+ data (Section 3.1).

\subsection{Results And Discussion}

\subsection{Spatial soil erodibility map}

A spatial soil erodibility map (Fig. 3) with an $\mathrm{R}^{2}$ of 0.63 for the validation dataset was produced from the DSM analysis. The most important predictors were slope, elevation, MrRTF, Band5d, ndvid and GVI. Given that no comprehensive model evaluation guideline was found on the model output, these results were compared with other published works. Avalos et al. (2018) reported $R^{2}$ values of 0.31 for DSM by using only terrain attributes and obtained a significant linear relationship between slope and erodibility. Panagos et al. (2014) reported an $\mathrm{R}^{2}$ of 0.74 on cross-validation when applying the cubist method with the Multi-level B splines interpolation technique with both spectral and terrain attributes. Although the combined use of these covariates improved the predictions, latitude and elevation covariates were ranked as the most important predictors. Taghizadeh-Mehrjardi et al. (2019) reported $\mathrm{R}^{2}$ values of 0.71 .

The importance of terrain factors may be attributed to the information they contain on landscape positioning. These covariates can discriminate between hillslopes which are dominated by erosion and transport processes and consequently high erodibility (Gallant and Dowling 2003; Jones et al. 2020). Noteworthy is the preference for MrRTF over MrVTF as a predictor. In general, the RUSLE equation does not account for depositional areas such as valley bottoms represented using the MrVFT (Alewell et al. 2019). The selection of the spectral data may be attributed to the information they contain on vegetation, which is one input source of soil organic matter. Taghizadeh-Mehrjardi et al. (2019) found a strong negative correlation between the K-factor and soil organic matter. Zhao et al. (2018) and Addis and Klik (2015) reported that soil erodibility has an indirect relationship with vegetation type, which influences the soil organic matter and soil particle distribution. This means that soil erodibility is a dynamic property that can be highly influenced by anthropogenic activities (Lal 2001).

According to Schwertmann (1987) erodibility can be classified as follows $(K<0.1-$ 'very low', $0.1<K<0.2$ - 'low', $0.2<\mathrm{K}<0.3-$ 'medium', $0.3<\mathrm{K}<0.5-$ 'high', $\mathrm{K}>0.5-$ 'very high'). Using this, $46 \%$ of the catchment would be ranked as either having medium or high erodibility (Fig. 3). The highest erodibility is observed in areas surrounding the indigenous forest on the western extreme of the catchment and the outer parts of the catchment on both the north and south extremes. Moreover, steeper slopes are classified as having higher erodibility as compared to lower slopes. Concerning the different LULCs as presented in Fig. 4, the highest $\mathrm{K}$ factors were recorded under cropland and bare land. The lowest $\mathrm{K}$-factors were recorded under some tea plantations and not under the indigenous forest as expected. The K-factor is affected by the complex interaction between the different environmental factors, which vary within the different LULC. For the silt dominated soils of the Loess Plateau of China, Zhao et al. (2018) reported that for native 
vegetation, soil properties and topography were the dominant factors influencing soil erodibility. For managed and restored vegetation, properties such as soil organic matter highly influenced erodibility (Zhao et al. 2018). Terrain factors such as slope and elevation influence the physical and chemical properties of soils leading to changes in soil particle composition and soil erodibility. Higher elevations were associated with soils having higher erosion of silt material, which are then deposited in the lower elevation (Zhao et al. 2018). Against this background, the presence of Andosol (usually having higher silt and organic matter content during formation) in the high elevation could have recorded lower K-factor values due to the effect of long-term erosion. Conversely, the use of high organic amendments such as mulch from pruned residues could explain the low erodibility observed under some tea plantations. The use of mulch protects the soil against the impact of raindrops in addition to increasing soil organic matter, which stabilises the soil aggregates, making them less prone to erosion ( $\mathrm{Ni}$ et al. 2016; Xianchen et al. 2020).

\subsection{Temporal and spatial soil erosion dynamics}

An initial overview of the spatial monthly soil erosion dynamics illustrated by Fig. 5 and Fig. 6 (see Appendix) shows that most of the soil loss occurs within two distinct periods. The first is between March and June and the second is between October and December. Furthermore, they reveal that the areas around the indigenous forest on the western and southern parts of the catchment have at the highest erosion risk. These are mostly deforested areas that are now either bare or have sparse shrub cover. Consequently, increased rainfall further increases the risk of erosion along the slopes in the Ruiru catchment. These results can be corroborated by Kamamia et al. (2021) who found that these areas are characterized by low aggregate stability and are therefore highly susceptible to erosion.

From Fig. 7a cumulative monthly soil loss of $2.23 \mathrm{t} / \mathrm{ha}$ and $1.68 \mathrm{t} / \mathrm{ha}$ was estimated from the long (March-0.11 t/ha/month, April-1.70 t/ha/month, May-0.43 t/ha/month) and short (October-0.56 $\mathrm{t} / \mathrm{ha} / \mathrm{month}$, November $-0.89 \mathrm{t} / \mathrm{ha} / \mathrm{month}$, December $-0.22 \mathrm{t} / \mathrm{ha} / \mathrm{month}$ ) rain seasons, respectively. The highest soil loss was observed in April, while the lowest soil loss of $0.003 \mathrm{t} / \mathrm{ha} / \mathrm{month}$ was observed in July. Ongoma (2019) reported that precipitation in Kenya reaches its peak in April and it is lowest in July. A monthly average of $0.27 \mathrm{t} / \mathrm{ha} / \mathrm{month}$ obtained from average cumulative yearly soil loss from the GloSEM would mean that the average soil loss in April is 6.3 times higher than the average cumulative yearly soil loss. The use of such averages for the design of erosion control measures could lead to the under-designing and construction of ineffective control measures. This situation could further be exacerbated where such measures fail, resulting in damage to crops and even loss of lives.

Soil loss can be described with two main mechanisms: erosion by raindrop impact and erosion by surface runoff. In reality, both mechanisms often come into play simultaneously. Thus, soil erosion mechanisms should be classified based on the degree of susceptibility of one mechanism relative to another (Toy et al. 2002; Kinnell 2005). There are two cropping seasons in the Ruiru Reservoir catchment that take advantage of the bimodal rainfall in the catchment. Before the onset of the rainy seasons, the soils are dry and thus possess high infiltration rates. Despite this, the soils are loose and bare due to tilling. At the start of the rains, the soils are more susceptible to erosion by raindrop impact. Over time, the 
soil pores gradually get saturated with water and therefore increased precipitation causes more raindrops to penetrate through the flow detaching soil particles which are then lifted and transported (Kinnell 2005). Higher soil loss recorded during the long rains is due to increased precipitation events. Wei et al. (2009) concluded that rainfall events with long durations but relatively low intensities play important roles in inducing severe erosion. Therefore, it is imperative to note that measures protecting the soil against rainfall drops (such as increased plant cover) would markedly reduce soil losses in the Ruiru catchment at the onset of rainfall.

\subsection{Soil loss dynamics under different LULC}

The soil loss trend observed in Fig. 8 for all months was BARE $>A G>T E A>N V$. Despite occupying the smallest areal portion- $4.8 \%$, bare land-BARE is the largest unit contributor to soil erosion. This LULC includes some deforested areas, areas around most homesteads and roadsides. Most of the feeder roads within the Ruiru catchment occur on steep slopes and are made of earthen material. They are constantly used by heavy vehicles that carry milk and tea from the many smallholder farmers to the various processing units. This impact compresses the roads forcing the edges to break away leaving the bare soils susceptible to water erosion. Cerdan et al. (2010) found a positive relationship between erosion rates and slope length on bare soils. As this LULC records the highest soil loss, vegetative or structural stabilisation of roadsides for example, by use of gabions (Laflen et al. 1985) could offer an all-year solution to mitigate the erosion risk in these areas. The establishment of grasses/turfs around homesteads and reafforestation in the areas surrounding the forests could protect the bare soil against erosion.

Cropland-AG-with an aerial coverage of $38.3 \%$ is the dominating land-use in the Ruiru catchment and recorded the second-highest soil loss in all the months of the year. Most of the farmers in the Ruiru catchment practice rain-fed mixed annual agriculture. At the onset of the long rains in March and short rains in November, the soils are usually tilled and sowed. Tilling activities destroy soil aggregates and lack of vegetation exposes the soil to the direct impact of raindrops. Exposure of the already loose soil to rain leads to severe denudation of the topsoil (Feng et al. 2016; Muoni et al. 2020; Nasir Ahmad et al. 2020). This variation also changes with the rainfall intensity with higher erosion rates being experienced during higher precipitation (Fig. 8). Adoption of more appropriate crop and tillage activities such as conservation tillage and strip-cropping could be used as a strategy to reduce the soil loss recorded at the onset of both the long and short rainfall. Mulching activities can further protect the soil surface from the erosive forces of raindrop impact and overland flow especially during times where crops are less developed. Finally, the adoption of agroforestry can serve as a more permanent solution to reducing erosion risk by water for this LULC.

Tea-TEA-growing in Ruiru catchment, mostly carried out along steep slopes, covers an area of $34.8 \%$. High soil loss may occur due to the general topography and poor management strategies (Krishnarajah 1985; Mupenzi et al. 2011). In consequence, soil erosion on top of slopes could lead to loss of productivity, which may be irreversible as the rate of soil loss greatly supersedes its formation rate. Soil loss in the tea plantations of the Ruiru Reservoir catchment could be due to 1.) new tea plantations, 
which contribute greatly to soil erosion and grown without any conservation measures further aggravate the soil loss and 2.) management activities such as pruning and weeding often lead to trampling, which loosens the soil, making it more susceptible to erosion. Soil loss in the tea plantations is particularly high within the first two months of the long (April and May) and short (October and November) rains. Before these months, productivity is usually low, there is largescale pruning and weeding in the catchment, as a result, the soil is loosened and exposed. This soil is then lost during the next rainy season. Contrary to this, some studies have concluded that well-managed tea bushes or developed tea bushes have soil erosion comparable to natural forests (Krishnarajah 1985; Allaway and Cox 1989). This study underpins this, as some tea plantations recorded lower erodibility values than forested areas. For Sri-Lanka, Krishnarajah (1985) reported that conservation measures such as mulching with pruning residues and grass cuttings as well as the use of terraces resulted in almost complete elimination of soil erosion in tea plantations along steep slopes. The author further observed that mulching during replanting reduced soil erosion. Reduction of water erosion risk for this LULC can be attained by applying mulch when establishing new tea plantations. Mulching before pruning and weeding activities could protect the soil against trampling which induces erosion.

Although the lowest soil erosion was recorded under NV, the value was slightly higher than expected. This is because this LULC included indigenous forest located on the western part of the catchment, afforested land and grasslands/shrublands. Afforested lands are part of an initiative by the Kenya Forestry Service (KFS) to restore degraded or deforested areas using mixed-species indigenous trees. Some of the afforested areas contain young tree stands. In addition to possessing underdeveloped tree canopies, spacing between planted trees is usually wider than plants as this is dependent on their mature canopy spread (Oliveira et al. 2013). This leaves a lot of open spaces where the impact of raindrops is much higher due to the lack of canopy, litter and underdeveloped tree roots (Drzewiecki et al. 2014). Over time, the trees' canopies develop. Thus the leaf area index increases and there is increased litter that forms a mulch layer on the soil surface (Oliveira et al. 2013). Only then are the trees efficiently capable of controlling soil erosion while increasing soil biomass as in the case of indigenous ones. Nevertheless, the major advantages associated with trees, especially indigenous, should be exploited through the adoption of agroforestry systems. During the formative years, the crops can provide ground cover for the young trees. The trees would then later on control soil erosion and increase base flow through increased infiltration and by ensuring that soils are never completely unprotected (Nair 2008). This was observed by Ligonja and Shrestha (2015) who concluded that on-farm tree planting contributed significantly to a 7\% reduction of areas under very high erosion severity between 1986-2008 in addition to increasing flow during the dry periods in Kondoa area, Tanzania. Likewise, Nambajimana et al.(2020) recommended a reforestation scheme of rapidly growing tree species as an important feature for erosion control in eroded areas of Rwanda. Waithaka et al. (2020) reported that most grasslands and shrublands (now occupying $\sim 6 \%$ of the catchment) have been converted into settlement areas in Ruiru catchment. The remaining scattered portions serve as alternate pasture for the dairy cattle in the catchment. Grasslands/shrublands have shown the potential to reduce soil erosion. For example, a study by Keller et al. (2019) compared the soil erosion potential between arable land and grassland using rainfall simulation experiments with 
varying rainfall intensities and durations. The results revealed that runoff and additionally sediment load was ten folds higher in arable land as compared to grassland/shrublands. This can be attributed to the fibrous roots which spread out superficially within the topsoil layer increasing soil shear strength (Mutegi et al. 2008).

Thus, it is clear that vegetation coverage is an important factor for soil erosion, as it reduces the direct impact of rain drops and alleviates runoff through increased infiltration which finally affects the quality of surface and river runoff (Cerdan et al. 2010; Feng et al. 2016). It should be however noted that extreme rainfall, such as that received in April, may at times increase the uncertainty of the effectiveness of vegetation in reducing erosion (Wei et al. 2009). Finally, the spatial distribution of vegetation on the slopes is a key factor for the Ruiru Reservoir catchment. This affects the source-sink spatial landscape patterns which influence the runoff generation and sediment transport (Liu et al. 2018). For instance, if done properly, adjusting vegetation patterns along a slope could greatly reduce soil loss into the Ruiru Reservoir.

\subsection{Conclusion}

Within this study, it was found that yearly erosion risk maps misrepresent the true dimensions of soil loss with averages disguising areas of low and high potential. At times, a small portion of the catchment is responsible for a large proportion of the total erosion. This was clearly exhibited by the bare land LULC that was the largest contributor to erosion. Thus, it is only natural that erosion control in such areas can greatly reduce soil loss and siltation. The monthly erosion maps reveal that the long rains between March and May lead to a higher soil loss than the short rains received between October and December. Both the R-factor and C-factor greatly impact the dynamics of soil loss in the Ruiru catchment, and while the spatiotemporal distribution of rainfall is largely uncontrollable, the crop management factor is greatly influenced by the type and intensity of human intervention.

Sustainable soil management improves soil functions which impact positively on the SDGs. Suitable indicators such as the soil erosion are needed to transfer the complexity of the soil-water system into a format that can be assessed and measured. More often these indicators have not been well explored and little or no data is available in developing countries. For proper implementation of the nexus approach, there is need to close the gap between data collection, data analysis and information generation. Here, we established that monthly soil loss maps can be developed through limited data collection, satellite data and the application of digital soil mapping techniques. Landscape scale measures including timely allocation of scarce erosion mitigation and protection measures, proper crop selection that reduces erosion, as well as time-dependent planting and harvesting techniques for agriculture, can be purposely incorporated. Such maps can be used by different stakeholders during the development of watershed management plans (Mwangi et al. 2016).

In the context of integrated water resource management in the Ruiru catchment, a successful watershed management plan will require joint effort from the different stakeholders-small-scale 
farmers/communities, large-scale tea estate farmers, The Nairobi Water and Sewerage Company and the Kenya Forest Service. The roles of the different stakeholders in coordinating and implementing any measures must clearly be stipulated and timelines need to be incorporated. In particular, the communities within the catchment must be empowered to develop the management of soils sustainably through outreach and capacity development programs. They should not only aim at safeguarding the water sources but also maintaining /improving land productivity and ecological soil functions (Calder 2006; Lal et al. 2017). Finally, it is essential to ensure that a comprehensive monitoring and evaluation system is established to assess the impact of the measures and to address any arising issues. Only then will the sustainable use of soil and water resources in the catchment of the drinking water reservoir be achieved.

\section{Declarations}

\section{ACKNOWLEDGEMENTS}

We appreciate the assistance of Samuel Nderitu, Jackson Warui (Water Resource Users Association), Daniel Waweru (Kenya Forestry Service) during fieldwork. The work was funded by the Graduate Academy, TU Dresden through the Travel Grants for Short-Term Research stays abroad and the Scholarship Program for the Promotion of Early-Career Female Scientists scholarship programs.

Funding: Graduate Academy, TU Dresden through the Travel Grants for Short-Term Research stays abroad and the Scholarship Program for the Promotion of Early-Career Female Scientists scholarship programs.

\section{Conflicts of interest/Competing interests: N/A}

\section{Availability of data and material: N/A}

Code availability: Software application

\section{References}

1. Addis HK, Klik A (2015) Predicting the spatial distribution of soil erodibility factor using USLE nomograph in an agricultural watershed, Ethiopia. Int Soil Water Conserv Res 3:282-290. https://doi.org/10.1016/j.iswcr.2015.11.002

2. Alewell C, Borrelli P, Meusburger K, Panagos $P$ (2019) Using the USLE: Chances, challenges and limitations of soil erosion modelling. Int Soil Water Conserv Res 7:203-225. https://doi.org/10.1016/j.iswcr.2019.05.004

3. Alexandridis TK, Sotiropoulou AM, Bilas G, et al (2015) The Effects of Seasonality in Estimating the C-Factor of Soil Erosion Studies. Land Degrad Dev 26:596-603. https://doi.org/10.1002/ldr.2223

4. Allaway J, Cox PMJ (1989) Forests and competing land uses in Kenya. Environ Manage 13:171187. https://doi.org/10.1007/BF01868364 
5. Almagro A, Thomé TC, Colman CB, et al (2019) Improving cover and management factor (C-factor) estimation using remote sensing approaches for tropical regions. Int Soil Water Conserv Res 7:325334. https://doi.org/10.1016/j.iswcr.2019.08.005

6. Ampofo EA, Muni RK, Bonsu M (2002) Estimation of soil losses within plots as affected by different agricultural land management. Hydrol Sci J 47:957-967. https://doi.org/10.1080/02626660209493003

7. Angima SD, Stott DE, O'Neill MK, et al (2003) Soil erosion prediction using RUSLE for central Kenyan highland conditions. Agric Ecosyst Environ 97:295-308. https://doi.org/10.1016/S01678809(03)00011-2

8. Angulo-Martínez M, López-Vicente M, Vicente-Serrano SM, Beguería S (2009) Mapping rainfall erosivity at a regional scale: a comparison of interpolation methods in the Ebro Basin (NE Spain). Hydrol Earth Syst Sci 13:1907-1920. https://doi.org/10.5194/hess-13-1907-2009

9. Asis A, Omasa K (2007) Estimation of vegetation parameter for modeling soil erosion using linear Spectral Mixture Analysis of Landsat ETM data. https://doi.org/10.1016/J.ISPRSJPRS.2007.05.013

10. Avalos FAP, Silva MLN, Batista PVG, et al (2018) Digital soil erodibility mapping by soilscape trending and kriging. Land Degrad Dev 29:3021-3028. https://doi.org/10.1002/ldr.3057

11. Benediktsson JA, Swain PH, Ersoy OK (1990) Neural Network Approaches Versus Statistical Methods in Classification of Multisource Remote Sensing Data. IEEE Trans Geosci Remote Sens 28:540-552. https://doi.org/10.1109/TGRS.1990.572944

12. Boardman J, Evans R (2019) The measurement, estimation and monitoring of soil erosion by runoff at the field scale: Challenges and possibilities with particular reference to Britain. Prog Phys Geogr Earth Environ 030913331986183. https://doi.org/10.1177/0309133319861833

13. Borrelli P, Robinson DA, Fleischer LR, et al (2017) An assessment of the global impact of 21 st century land use change on soil erosion. Nat Commun 8:2013. https://doi.org/10.1038/s41467-017-02142-7

14. Calder IR (2006) Integrated Land and Water Resources Management. In: Encyclopedia of Hydrological Sciences. American Cancer Society

15. Carr DL (2004) Proximate Population Factors and Deforestation in Tropical Agricultural Frontiers. Popul Environ 25:585-612. https://doi.org/10.1023/B:POEN.0000039066.05666.8d

16. Cerdan O, Govers G, Le Bissonnais Y, et al (2010) Rates and spatial variations of soil erosion in Europe: A study based on erosion plot data. Geomorphology 122:167-177. https://doi.org/10.1016/j.geomorph.2010.06.011

17. Climate Hazards Center - UC Santa Barbara (2020) CHIRPS: Rainfall Estimates from Rain Gauge and Satellite Observations. https://www.chc.ucsb.edu/data/chirps. Accessed 7 Nov 2020

18. Conrad O, Bechtel B, Bock M, et al (2015) System for Automated Geoscientific Analyses (SAGA) v. 2.1.4. Geosci Model Dev 8:1991-2007. https://doi.org/10.5194/gmd-8-1991-2015

19. Dragičević N, Karleuša B, Ožanić N (2018) Modification of erosion potential method using climate and land cover parameters. Geomat Nat Hazards Risk 9:1085-1105.

https://doi.org/10.1080/19475705.2018.1496483

Page 18/30 
20. Drzewiecki W, Wężyk P, Pierzchalski M, Szafrańska B (2014) Quantitative and Qualitative Assessment of Soil Erosion Risk in Małopolska (Poland), Supported by an Object-Based Analysis of High-Resolution Satellite Images. Pure Appl Geophys 171:867-895. https://doi.org/10.1007/s00024013-0669-7

21. Duiker SW, Flanagan DC, Lal R (2001) Erodibility and infiltration characteristics of five major soils of southwest Spain. Catena 45:103-121. https://doi.org/10.1016/S0341-8162(01)00145-X

22. Dutta S (2016) Soil erosion, sediment yield and sedimentation of reservoir: a review. Model Earth Syst Environ 2:123. https://doi.org/10.1007/s40808-016-0182-y

23. EarthExplorer (2019) USGS. https://earthexplorer.usgs.gov/. Accessed 10 Mar 2020

24. Ebabu K, Tsunekawa A, Haregeweyn N, et al (2019) Effects of land use and sustainable land management practices on runoff and soil loss in the Upper Blue Nile basin, Ethiopia. Sci Total Environ 648:1462-1475. https://doi.org/10.1016/j.scitotenv.2018.08.273

25. Feng Q, Zhao W, Wang J, et al (2016) Effects of Different Land-Use Types on Soil Erosion Under Natural Rainfall in the Loess Plateau, China. Pedosphere 26:243-256. https://doi.org/10.1016/S1002-0160(15)60039-X

26. Gallant JC, Dowling TI (2003) A multiresolution index of valley bottom flatness for mapping depositional areas. Water Resour Res 39:. https://doi.org/10.1029/2002WR001426

27. Ganasri BP, Ramesh H (2016) Assessment of soil erosion by RUSLE model using remote sensing and GIS - A case study of Nethravathi Basin. Geosci Front 7:953-961. https://doi.org/10.1016/j.gsf.2015.10.007

28. Gaubi I, Chaabani A, Ben Mammou A, Hamza MH (2017) A GIS-based soil erosion prediction using the Revised Universal Soil Loss Equation (RUSLE) (Lebna watershed, Cap Bon, Tunisia). Nat Hazards 86:219-239. https://doi.org/10.1007/s11069-016-2684-3

29. Hadi F, Yrle F, Gunasekara K (2018) Satellite Image Classification. In: QGIS: Basic Training

30. Haregeweyn N, Tsunekawa A, Poesen J, et al (2017) Comprehensive assessment of soil erosion risk for better land use planning in river basins: Case study of the Upper Blue Nile River. Sci Total Environ 574:95-108. https://doi.org/10.1016/j.scitotenv.2016.09.019

31. Hatfield JL, Sauer TJ, Cruse RM (2017) Chapter One - Soil: The Forgotten Piece of the Water, Food, Energy Nexus. In: Sparks DL (ed) Advances in Agronomy. Academic Press, pp 1-46

32. Igwe PU, Onuigbo AA, Chinedu OC, et al (2017) Soil Erosion: A Review of Models and Applications. Int J Adv Eng Res Sci 4:237341

33. Iserloh T, Ries JB, Arnáez J, et al (2013) European small portable rainfall simulators: A comparison of rainfall characteristics. Catena 110:100-112. https://doi.org/10.1016/j.catena.2013.05.013

34. Jenny H (1941) Factors of Soil Formation, a system of quantitative pedology. McGraw-Hill, New York

35. Jones EJ, Filippi P, Wittig R, et al (2020) Mapping soil slaking index and assessing the impact of management in a mixed agricultural landscape. SOIL Discuss 1-22. https://doi.org/10.5194/soil2020-29 
36. Jong SM de (1994) Applications of reflective remote sensing for land degradation studies in a Mediterranean environment. Koninklijk Nederlands Aardrijkskundig Genootschap

37. Kamamia AW, Vogel C, Mwangi HM, et al (2021) Mapping soil aggregate stability using digital soil mapping: A case study of Ruiru reservoir catchment, Kenya. Geoderma Reg 24: e00355. https://doi.org/10.1016/j.geodrs.2020.e00355

38. Keller B, Szabó J, Centeri C, et al (2019) Different land-use intensities and their susceptibility to soil erosion. Agrokém És Talajt 68:14-23. https://doi.org/10.1556/0088.2018.00004

39. Khodadadi M, Mabit L, Zaman M, et al (2019) Using 137Cs and 210Pbex measurements to explore the effectiveness of soil conservation measures in semi-arid lands: a case study in the Kouhin region of Iran. J Soils Sediments 19:2103-2113. https://doi.org/10.1007/s11368-018-2205-y

40. Kidane M, Bezie A, Kesete N, Tolessa T (2019) The impact of land use and land cover (LULC) dynamics on soil erosion and sediment yield in Ethiopia. Heliyon 5: . https://doi.org/10.1016/j.heliyon.2019.e02981

41. Kinnell PIA (2005) Raindrop-impact-induced erosion processes and prediction: a review. Hydrol Process 19:2815-2844. https://doi.org/10.1002/hyp.5788

42. Kouli M, Soupios P, Vallianatos F (2009) Soil erosion prediction using the Revised Universal Soil Loss Equation (RUSLE) in a GIS framework, Chania, Northwestern Crete, Greece. Environ Geol 57:483-497. https://doi.org/10.1007/s00254-008-1318-9

43. Krishnarajah P (1985) Soil erosion control measures for tea land in Sri Lanka

44. Krysanova V, Müller-Wohlfeil D-I, Becker A (1998) Development and test of a spatially distributed hydrological/water quality model for mesoscale watersheds. Ecol Model 106:261-289. https://doi.org/10.1016/S0304-3800(97)00204-4

45. Laflen JM, Highfill RE, Amemiya M, Mutchler CK (1985) Structures and Methods for Controlling Water Erosion. In: Soil Erosion and Crop Productivity. John Wiley \& Sons, Ltd, pp 431-442

46. Lal R (2001) Soil degradation by erosion. Land Degrad Dev 12:519-539. https://doi.org/10.1002/ldr.472

47. Lal R, Mohtar RH, Assi AT, et al (2017) Soil as a Basic Nexus Tool: Soils at the Center of the FoodEnergy-Water Nexus. Curr Sustain Energy Rep 4:117-129. https://doi.org/10.1007/s40518-0170082-4

48. Lambin EF, Geist HJ, Lepers E (2003) Dynamics of Land-Use and Land-Cover Change in Tropical Regions. Annu Rev Environ Resour 28:205-241. https://doi.org/10.1146/annurev.energy.28.050302.105459

49. Ligonja PJ, Shrestha RP (2015) Soil Erosion Assessment in Kondoa Eroded Area in Tanzania using Universal Soil Loss Equation, Geographic Information Systems and Socioeconomic Approach. Land Degrad Dev 26:367-379. https://doi.org/10.1002/ldr.2215

50. Liu J, Gao G, Wang S, et al (2018) The effects of vegetation on runoff and soil loss: Multidimensional structure analysis and scale characteristics. J Geogr Sci 28:59-78. https://doi.org/10.1007/s11442-018-1459-z 
51. Ma Y, Minasny B, Wu C (2017) Mapping key soil properties to support agricultural production in Eastern China. Geoderma Reg 10:144-153. https://doi.org/10.1016/j.geodrs.2017.06.002

52. Maina CW, Sang JK, Mutua BM, Raude JM (2018) A review of radiometric analysis on soil erosion and deposition studies in Africa. Geochronometria 45:10-19. https://doi.org/10.1515/geochr-20150085

53. Maloi SK, Sang JK, Raude JM, et al (2016) Assessment of Sedimentation Status of Ruiru Reservoir, Central Kenya. http://pubs.sciepub.com. Accessed 25 Nov 2019

54. Malone BP, Minasny B, McBratney AB (2017) Using R for Digital Soil Mapping, 1st ed. 2017 Edition. Springer, New York, NY

55. McBratney AB, Mendonça Santos ML, Minasny B (2003) On digital soil mapping. Geoderma 117:352. https://doi.org/10.1016/S0016-7061(03)00223-4

56. Minasny B, McBratney AB (2006) A conditioned Latin hypercube method for sampling in the presence of ancillary information. Comput Geosci 32:1378-1388. https://doi.org/10.1016/j.cageo.2005.12.009

57. Montanarella L, Pennock D, McKenzie N, et al (2015) Status of the world's soil resources. Rome 58. Morgan RPC, Quinton JN, Smith RE, et al (1998) The European Soil Erosion Model (EUROSEM): a dynamic approach for predicting sediment transport from fields and small catchments. Earth Surf Process Landf 23:527-544. https://doi.org/10.1002/(SICI)1096-9837(199806)23:6<527: AIDESP868>3.0.CO;2-5

59. Mulinge W, Gicheru P, Murithi F, et al (2016) Economics of Land Degradation and Improvement in Kenya. In: Nkonya E, Mirzabaev A, von Braun J (eds) Economics of Land Degradation and Improvement - A Global Assessment for Sustainable Development. Springer International Publishing, Cham, pp 471-498

60. Muoni T, Koomson E, Öborn I, et al (2020) Reducing soil erosion in smallholder farming systems in east Africa through the introduction of different crop types. Exp Agric 56:183-195. https://doi.org/10.1017/S0014479719000280

61. Mupenzi J de la P, Li L, Ge J, et al (2011) Assessment of soil degradation and chemical compositions in Rwandan tea-growing areas. Geosci Front 2:599-607. https://doi.org/10.1016/j.gsf.2011.05.003

62. Mutegi JK, Mugendi DN, Verchot LV, Kung'u JB (2008) Combining napier grass with leguminous shrubs in contour hedgerows controls soil erosion without competing with crops. Agrofor Syst 74:37-49. https://doi.org/10.1007/s10457-008-9152-3

63. Mwangi HM, Julich S, Patil SD, et al (2016) Modelling the impact of agroforestry on hydrology of Mara River Basin in East Africa. Hydrol Process 30:3139-3155. https://doi.org/10.1002/hyp.10852

64. Mwangi JK, Shisanya CA, Gathenya JM, et al (2015) A modeling approach to evaluate the impact of conservation practices on water and sediment yield in Sasumua Watershed, Kenya. J Soil Water Conserv 70:75-90. https://doi.org/10.2489/jswc.70.2.75

65. Nair PKR (2008) Agroecosystem management in the 21st century: It is time for a paradigm shift. J Trop Agric 46:1-12 
66. Nambajimana J de D, He X, Zhou J, et al (2020) Land Use Change Impacts on Water Erosion in Rwanda. Sustainability 12:50. https://doi.org/10.3390/su12010050

67. NASA (2013) Landsat 8 Bands | Landsat Science. https://landsat.gsfc.nasa.gov/landsat-8/landsat8-bands/. Accessed 5 Nov 2020

68. NASA (1999) Remote Sensing. https://earthobservatory.nasa.gov/features/RemoteSensing/remote_05.php. Accessed 5 Nov 2020

69. Nasir Ahmad NSB, Mustafa FB, Muhammad Yusoff S@ Y, Didams G (2020) A systematic review of soil erosion control practices on the agricultural land in Asia. Int Soil Water Conserv Res 8:103-115. https://doi.org/10.1016/j.iswcr.2020.04.001

70. Ni X, Song W, Zhang H, et al (2016) Effects of Mulching on Soil Properties and Growth of Tea Olive (Osmanthus fragrans). PLOS ONE 11: e0158228. https://doi.org/10.1371/journal.pone.0158228

71. Niedzielski T (ed) (2015) Satellite Technologies in Geoinformation Science. Birkhäuser Basel

72. Nyakundi R, Mwangi J, Makokha M, Obiero C (2017) Analysis of Rainfall Trends and Periodicity in Ruiru Location, Kenya. Nternational J Sci Res Publ 7:28-39

73. Oliveira PT, Wendland E, Nearing MA (2013) Rainfall erosivity in Brazil: A review. Catena 100:139147. https://doi.org/10.1016/j.catena.2012.08.006

74. Ongoma V (2019) Why Kenya's seasonal rains keep failing and what needs to be done. In: ReliefWeb. https://reliefweb.int/report/kenya/why-kenya-s-seasonal-rains-keep-failing-and-what-needs-bedone. Accessed 4 Feb 2020

75. Ozsoy G, Aksoy E, Dirim MS, Tumsavas Z (2012) Determination of soil erosion risk in the Mustafakemalpasa River Basin, Turkey, using the revised universal soil loss equation, geographic information system, and remote sensing. Environ Manage 50:679-694. https://doi.org/10.1007/s00267-012-9904-8

76. Panagos P, Meusburger K, Ballabio C, et al (2014) Soil erodibility in Europe: A high-resolution dataset based on LUCAS. Sci Total Environ 479-480:189-200. https://doi.org/10.1016/j.scitotenv.2014.02.010

77. Patil RJ (2018) Spatial Techniques for Soil Erosion Estimation. In: Patil RJ (ed) Spatial Techniques for Soil Erosion Estimation: Remote Sensing and GIS Approach. Springer International Publishing, Cham, pp 35-49

78. QGIS.org (2019) QGIS Geographic Information System. Version 3.4. Open Source Geospatial Foundation Project. URL https://qgis.org/de/site/

79. Quero G, Simondi S, Borsani O (2015) Segmental interpolation surface: a tool to dissect environmental effects on plant water-use efficiency in drought prone scenarios. bioRxiv 033308. https://doi.org/10.1101/033308

80. Quinlan JR (1992) Learning with Continuous Classes. World Scientific, pp 343-348

81. R Core Team (2019) R: A Language and Environment for Statistical Computing. https://www.rproject.org/. Accessed 10 Mar 2020 
82. Renard KG, Laflen JM, Foster GR, et al (2017) The Revised Universal Soil Loss Equation. In: Soil Eros. Res. Methods. https://www.taylorfrancis.com/. Accessed 15 Jul 2020

83. Rientjes THM, Haile AT, Kebede E, et al (2011) Changes in land cover, rainfall and stream flow in Upper Gilgel Abbay catchment, Blue Nile basin - Ethiopia. Hydrol Earth Syst Sci 15:1979-1989. https://doi.org/10.5194/hess-15-1979-2011

84. Ries J, Iserloh T, Seeger M, Gabriels D (2013) Rainfall simulations - Constraints, needs and challenges for a future use in soil erosion research. Z Für Geomorphol Suppl Issues 57:1-10. https://doi.org/10.1127/0372-8854/2013/S-00130

85. Roudier P, Beaudette AE, Hewitt AE (2012) A conditioned Latin hypercube sampling algorithm incorporating operational constraints. In: Digital Soil Assessments and Beyond. pp 227-232

86. Schmidt S, Alewell C, Meusburger K (2018) Mapping spatio-temporal dynamics of the cover and management factor (C-factor) for grasslands in Switzerland. Remote Sens Environ 211:89-104. https://doi.org/10.1016/j.rse.2018.04.008

87. Schmidt S, Alewell C, Meusburger K (2019) Monthly RUSLE soil erosion risk of Swiss grasslands. J Maps 15:247-256. https://doi.org/10.1080/17445647.2019.1585980

88. Schmidt S, Alewell C, Panagos P, Meusburger K (2016) Regionalization of monthly rainfall erosivity patterns in Switzerland. Hydrol Earth Syst Sci 20:4359-4373. https://doi.org/10.5194/hess-20-43592016

89. Stroosnijder L (2005) Measurement of erosion: Is it possible? Catena 64:162-173. https://doi.org/10.1016/j.catena.2005.08.004

90. Taghizadeh-Mehrjardi R, Bawa A, Kumar S, et al (2019) Soil Erosion Spatial Prediction using Digital Soil Mapping and RUSLE methods for Big Sioux River Watershed. Soil Syst 3:43. https://doi.org/10.3390/soilsystems3030043

91. Tiwari H, Rai SP, Kumar D, Sharma N (2014) Rainfall erosivity factor for India using modified Fourier index. 4:83-91

92. Toy TJ, Foster GR, Renard KG (2002) Soil Erosion: Processes, Prediction, Measurement, and Control. John Wiley \& Sons

93. Uddin K, Murthy MSR, Wahid SM, Matin MA (2016) Estimation of Soil Erosion Dynamics in the Koshi Basin Using GIS and Remote Sensing to Assess Priority Areas for Conservation. PLOS ONE 11: e0150494. https://doi.org/10.1371/journal.pone.0150494

94. United Nations (2015) Transforming our world: the 2030 Agenda for Sustainable Development I Department of Economic and Social Affairs

95. Waithaka A, Murimi S, Obiero K (2020) Assessing the Effects of Land Use/Land Cover Change on Discharge Using SWAT Model in River Ruiru Watershed, Kiambu County, Kenya. Appl Ecol Environ Sci 8:303-314. https://doi.org/10.12691/aees-8-5-18

96. Wang G, Gertner G, Singh V, et al (2002) Spatial and temporal prediction and uncertainty of soil loss using the revised universal soil loss equation: a case study of the rainfall-runoff erosivity $\mathrm{R}$ factor. Ecol Model 153:143-155. https://doi.org/10.1016/S0304-3800(01)00507-5 
97. Wang J, He Q, Zhou P, Gong Q (2019) Test of the RUSLE and Key Influencing Factors Using GIS and Probability Methods: A Case Study in Nanling National Nature Reserve, South China. In: Adv. Civ. Eng. https://www.hindawi.com/journals/ace/2019/7129639/. Accessed 22 Jul 2020

98. Wei W, Chen L, Fu B, et al (2009) Responses of water erosion to rainfall extremes and vegetation types in a loess semiarid hilly area, NW China. Hydrol Process 23:1780-1791. https://doi.org/10.1002/hyp.7294

99. Wischmeier WH, Smith DD (1958) Rainfall energy and its relationship to soil loss. Eos Trans Am Geophys Union 39:285-291. https://doi.org/10.1029/TR039i002p00285

100. Wischmeier WH, Smith DD (1978) Predicting Rainfall Erosion Losses: A Guide to Conservation Planning. Department of Agriculture, Science and Education Administration

101. Xianchen Z, Huiguang J, Xiaochun W, Yeyun L (2020) The effects of different types of mulch on soil properties and tea production and quality. J Sci Food Agric 100:5292-5300. https://doi.org/10.1002/jsfa.10580

102. Young NE, Anderson RS, Chignell SM, et al (2017) A survival guide to Landsat preprocessing. Ecology 98:920-932. https://doi.org/10.1002/ecy.1730

103. Zhao W, Wei H, Jia L, et al (2018) Soil erodibility and its influencing factors on the Loess Plateau of China: a case study in the Ansai watershed. Solid Earth 9:1507-1516. https://doi.org/10.5194/se-91507-2018

104. Zhu B, Li Z, Li P, et al (2010) Soil erodibility, microbial biomass, and physical-chemical property changes during long-term natural vegetation restoration: a case study in the Loess Plateau, China. Ecol Res 25:531-541. https://doi.org/10.1007/s11284-009-0683-5

\section{Figures}




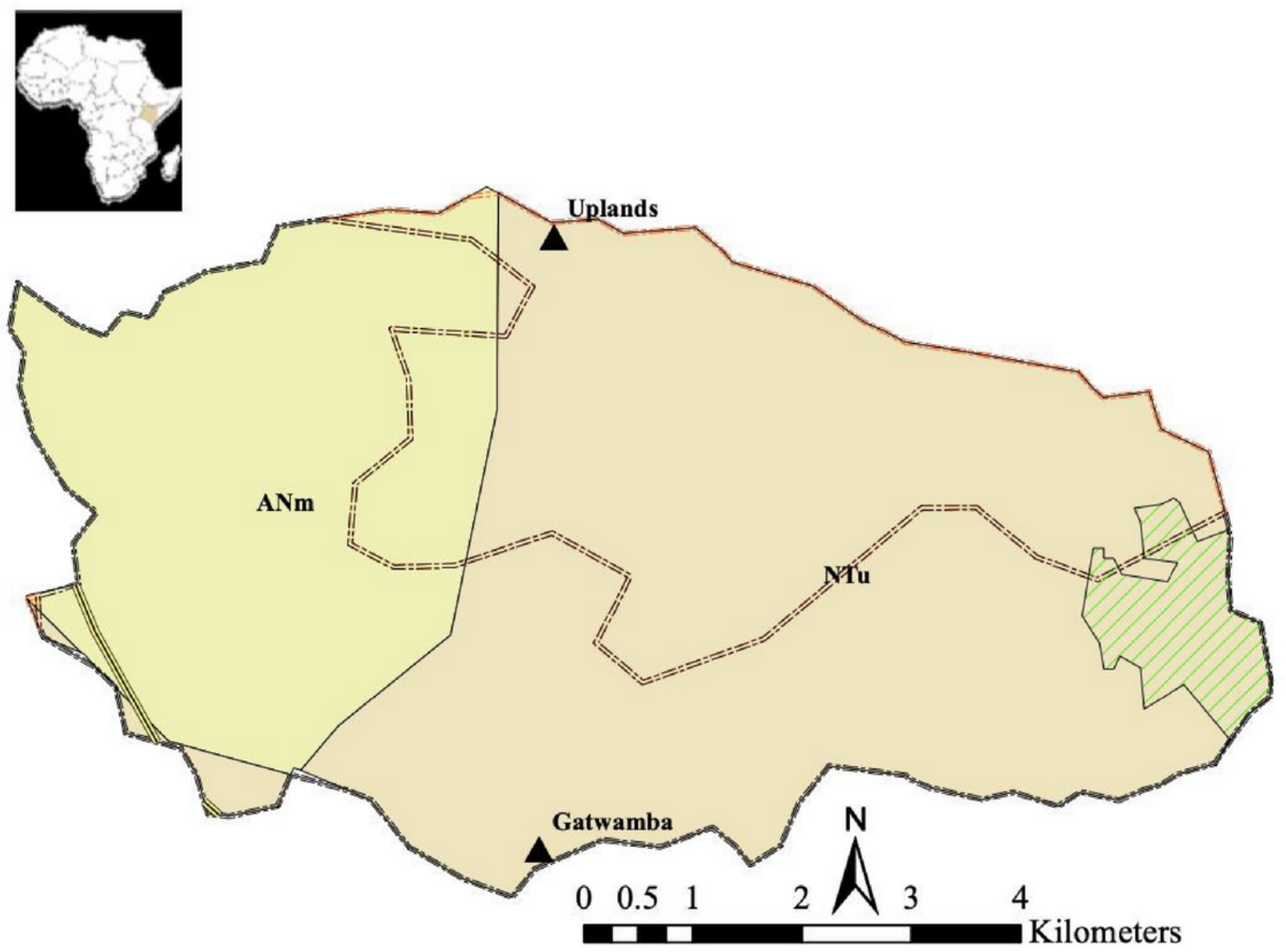

\section{Legend}

\begin{tabular}{|c|c|c|c|}
\hline Towns & Geology & Soils & \\
\hline Ruiru reservoir & Pv-Trachytes, phonolites and basalt & & ANm - Andosols \\
\hline Major Roads & $\|_{==:==j} \mathrm{Q} 2 \mathrm{v}-$ Basalt flows, pyroclastics, volcanic soils & & NTu - Nitisols \\
\hline & & & Ruiru catchment \\
\hline
\end{tabular}

\section{Figure 1}

The Ruiru Reservoir catchment in Central Kenya: soils, geology and location 


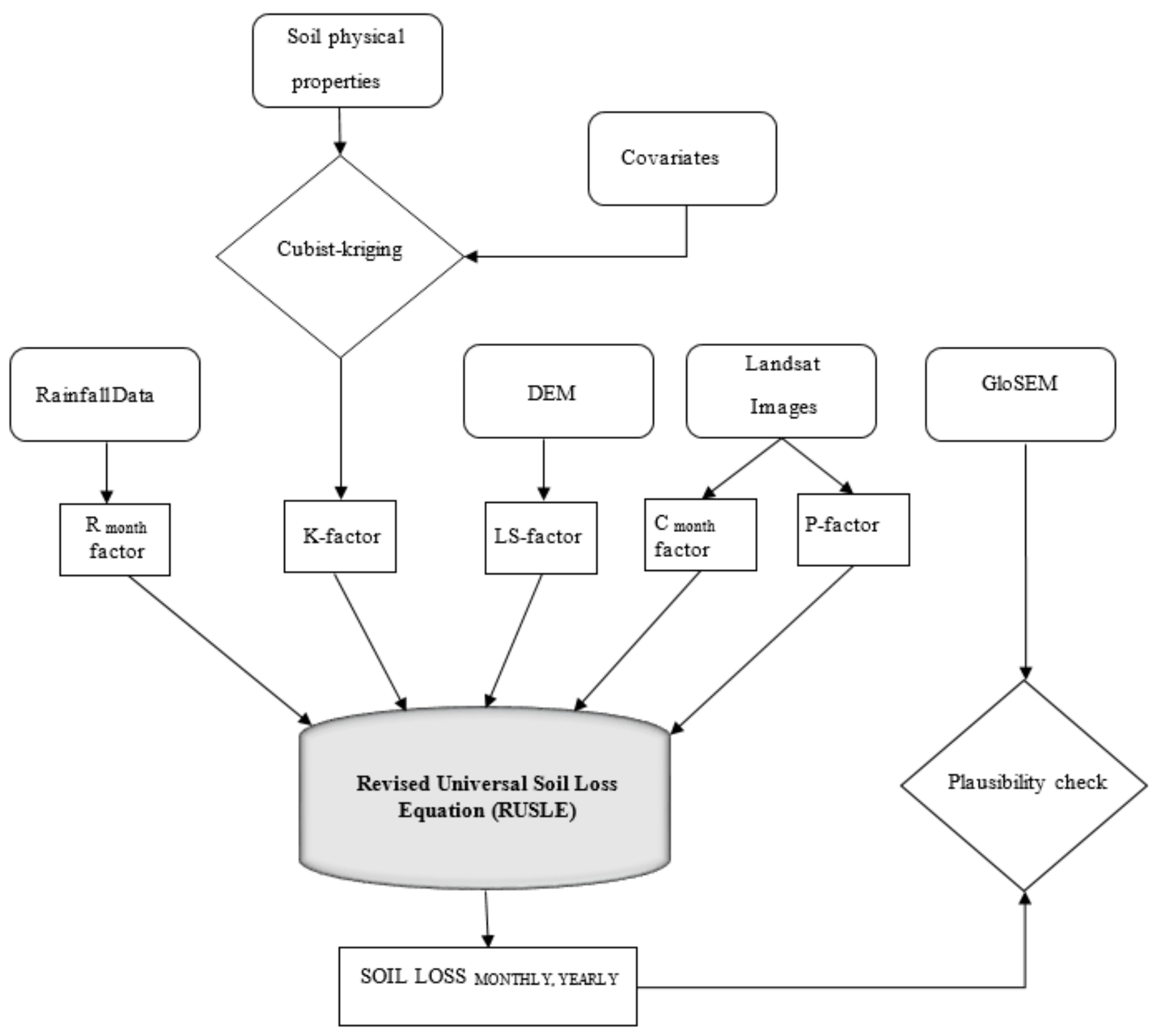

Figure 2

Flowchart of the application of RUSLE equation and plausibility check 


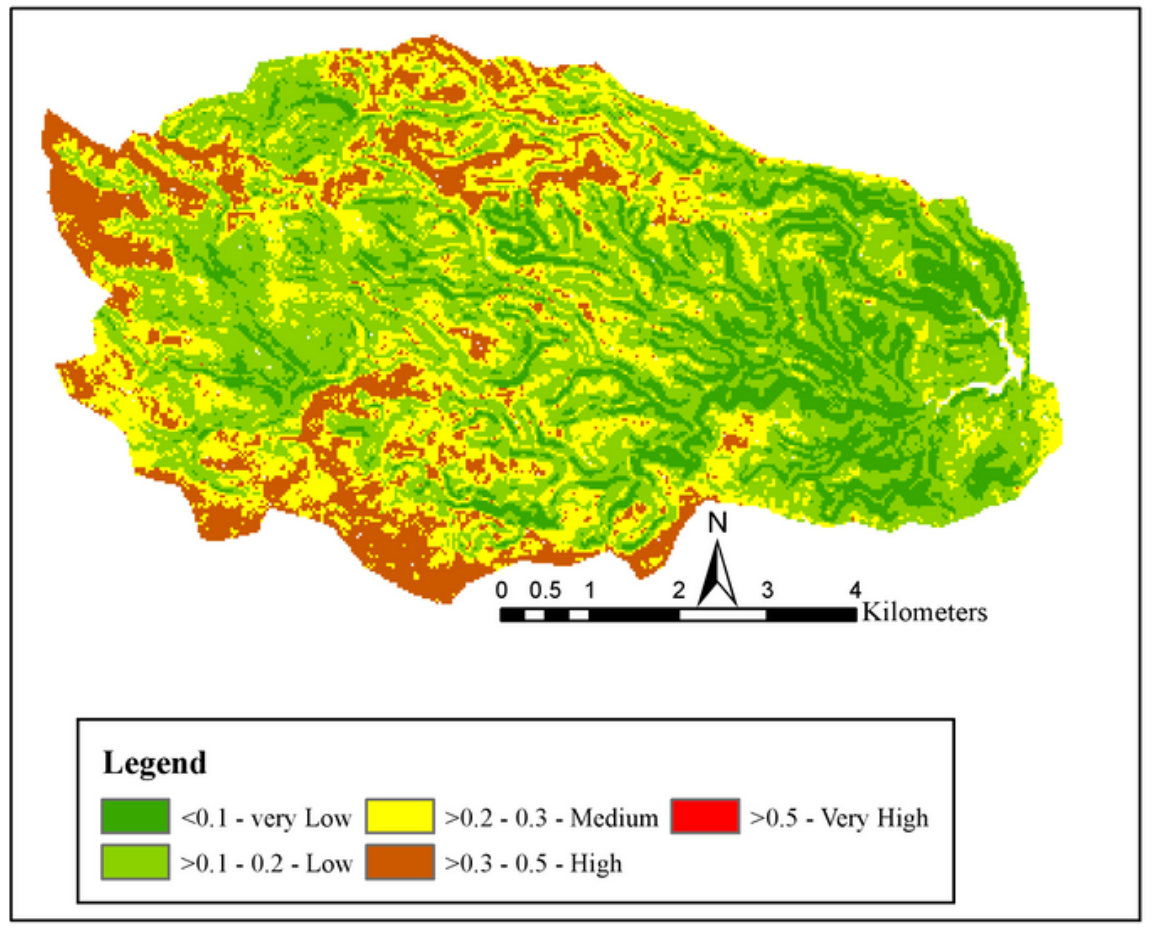

\section{Figure 3}

Spatial soil erodibility map of the Ruiru reservoir catchment 


\section{$\mathrm{K}$ factor for the different LULC}

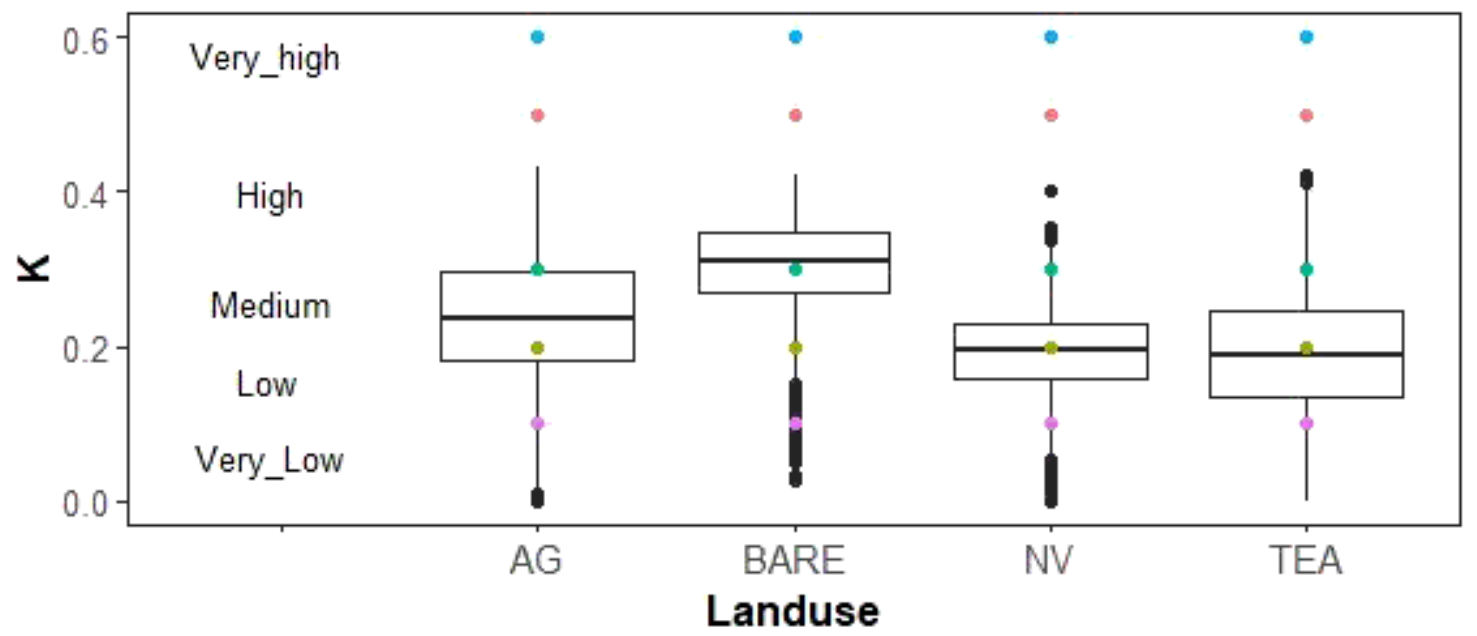

Classification - High - Low - Medium - Very_high - Very_Low

\section{Figure 4}

$\mathrm{K}$ factor for the different land use and land cover (LULC) in the Ruiru reservoir catchment AG-cropland, BARE-bare land, NV-natural vegetation, TEA-tea plantation

\section{Water erosion prediction (January-June)}

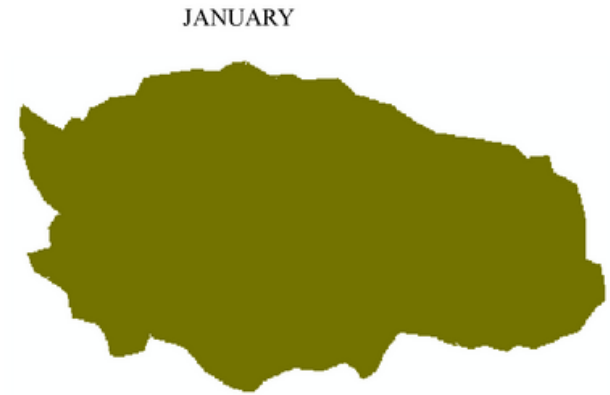

APRIL

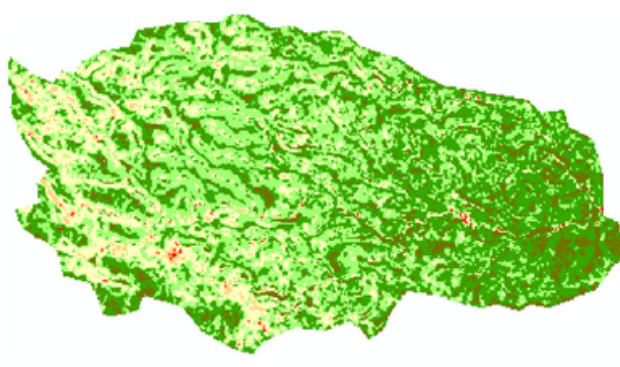

Monthly soil loss (t/ha/month)

0-0.1 $0.1-0.5$

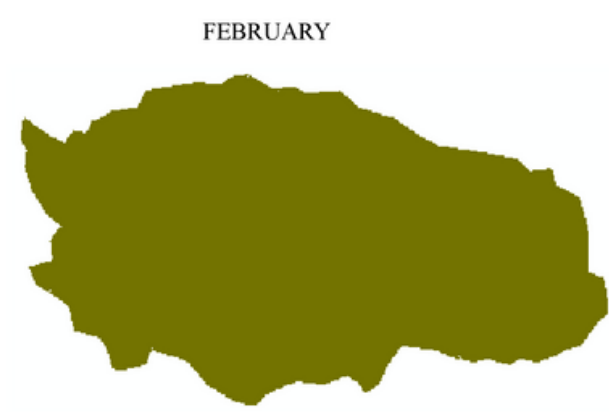

MAY

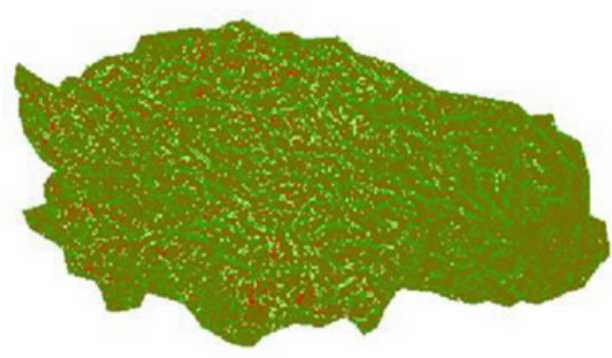

$>2-3$

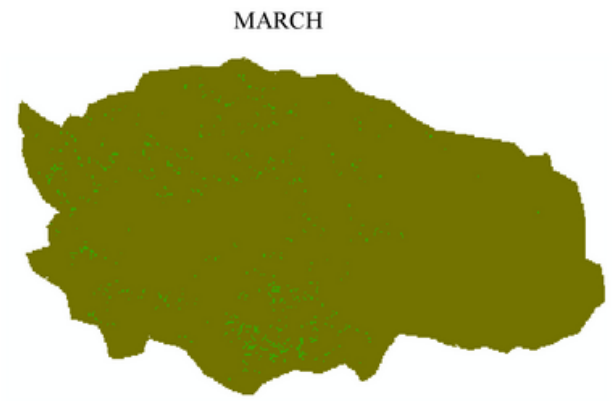

JUNE

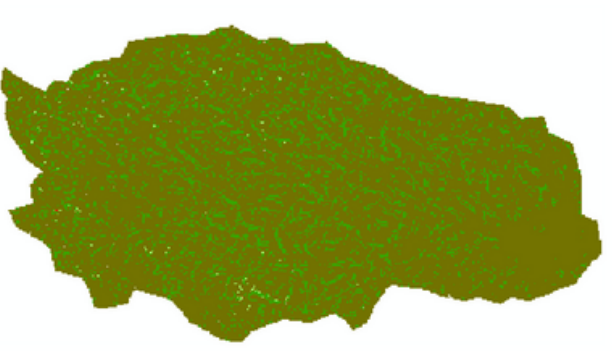

\section{Figure 5}

Water-erosion risk maps for the Ruiru drinking water reservoir catchment for January-June 
Water erosion prediction (July- December)

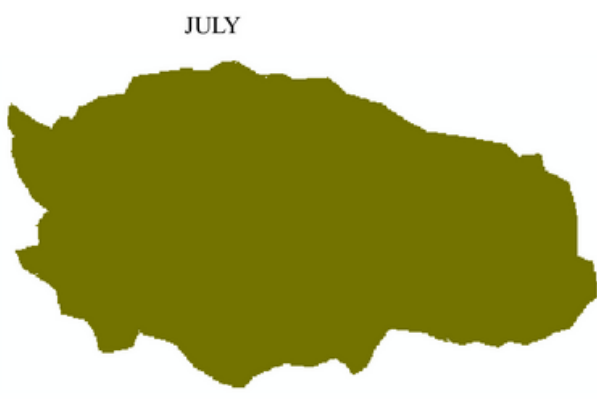

OCTOBER

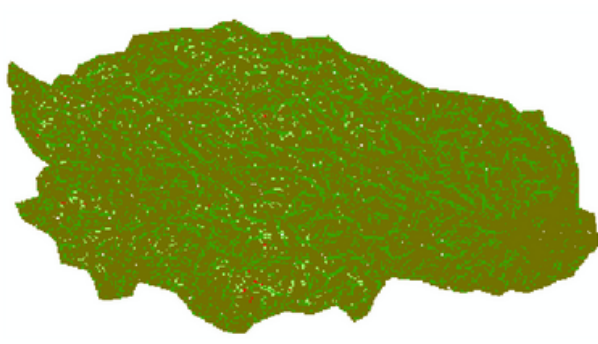

Monthly soil loss (t/ha/month)

\begin{tabular}{c}
$0-0.1 \square 0.1-0.5$ \\
\hline
\end{tabular}
AUGUST

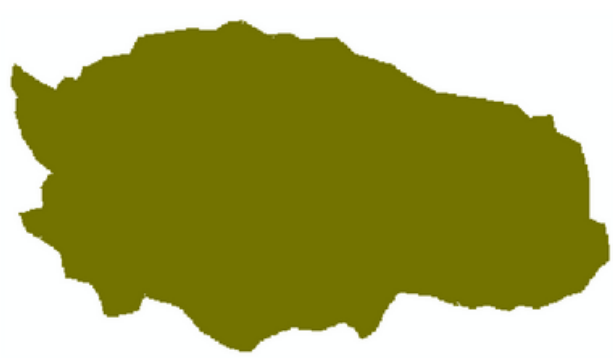

NOVEMBER

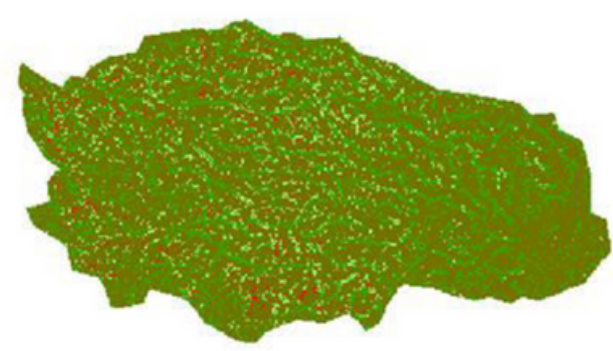

SEPTEMBER

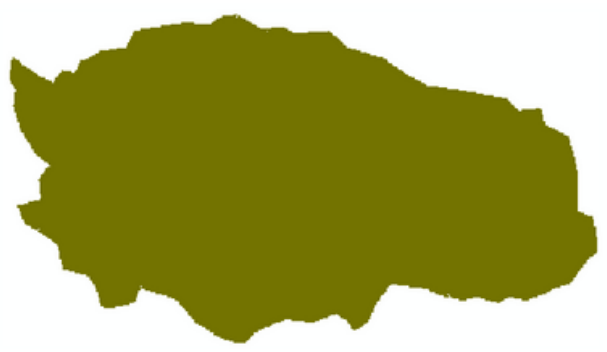

DECEMBER

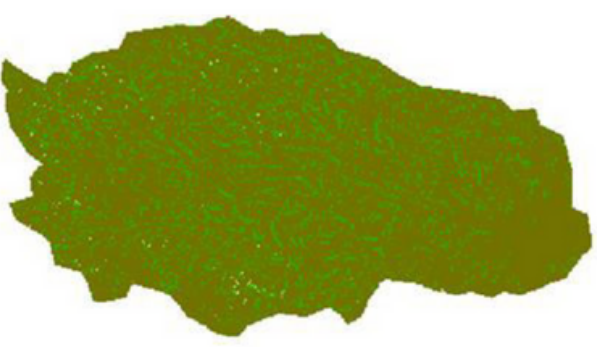

\section{Figure 6}

Water-erosion risk maps for the Ruiru drinking water reservoir catchment for July-December

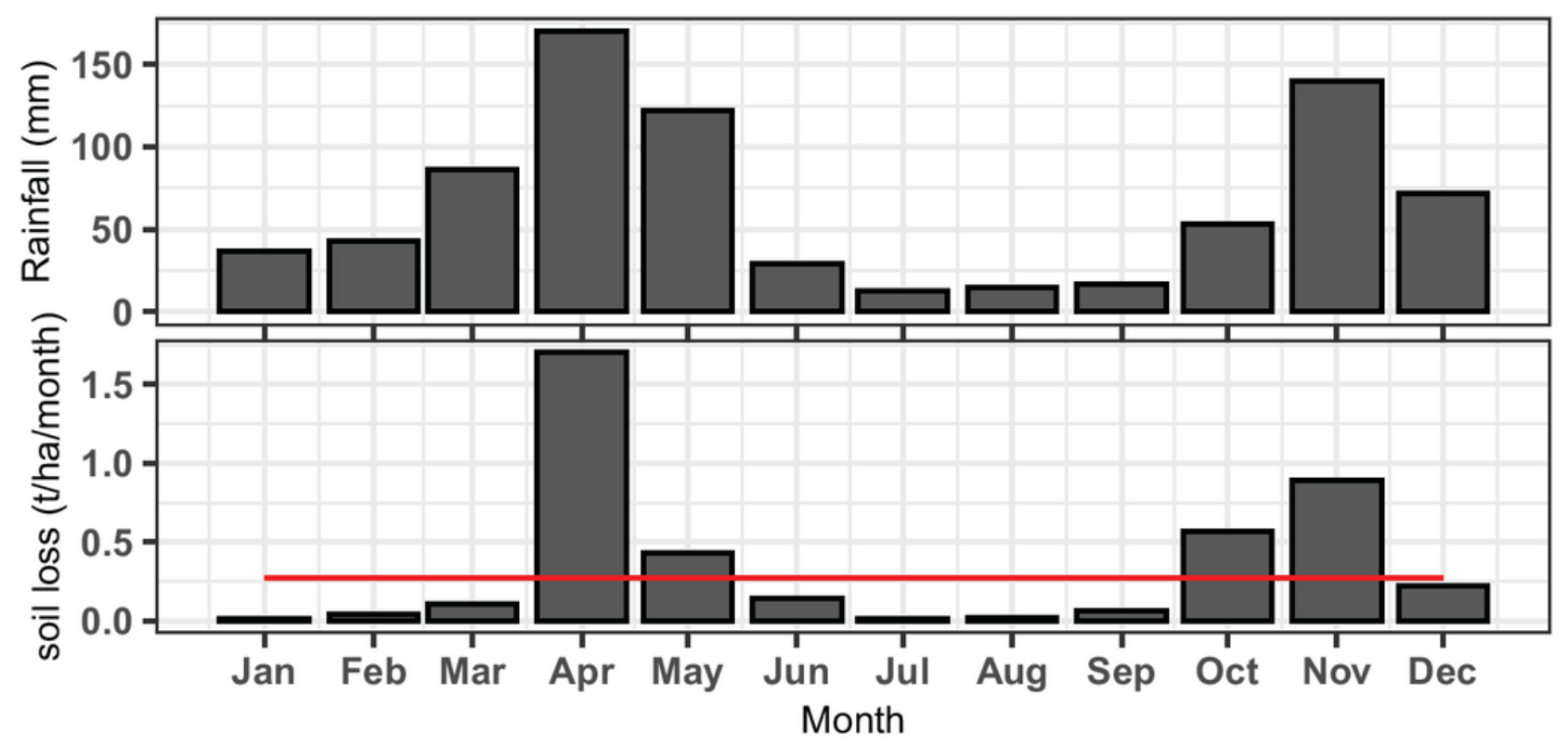

Figure 7 
Graph showing on the top: Line graph of monthly rainfall distribution On the bottom: Dynamic (REG_SLbar plot) and static (GloSEM-line graph) monthly water erosion risk

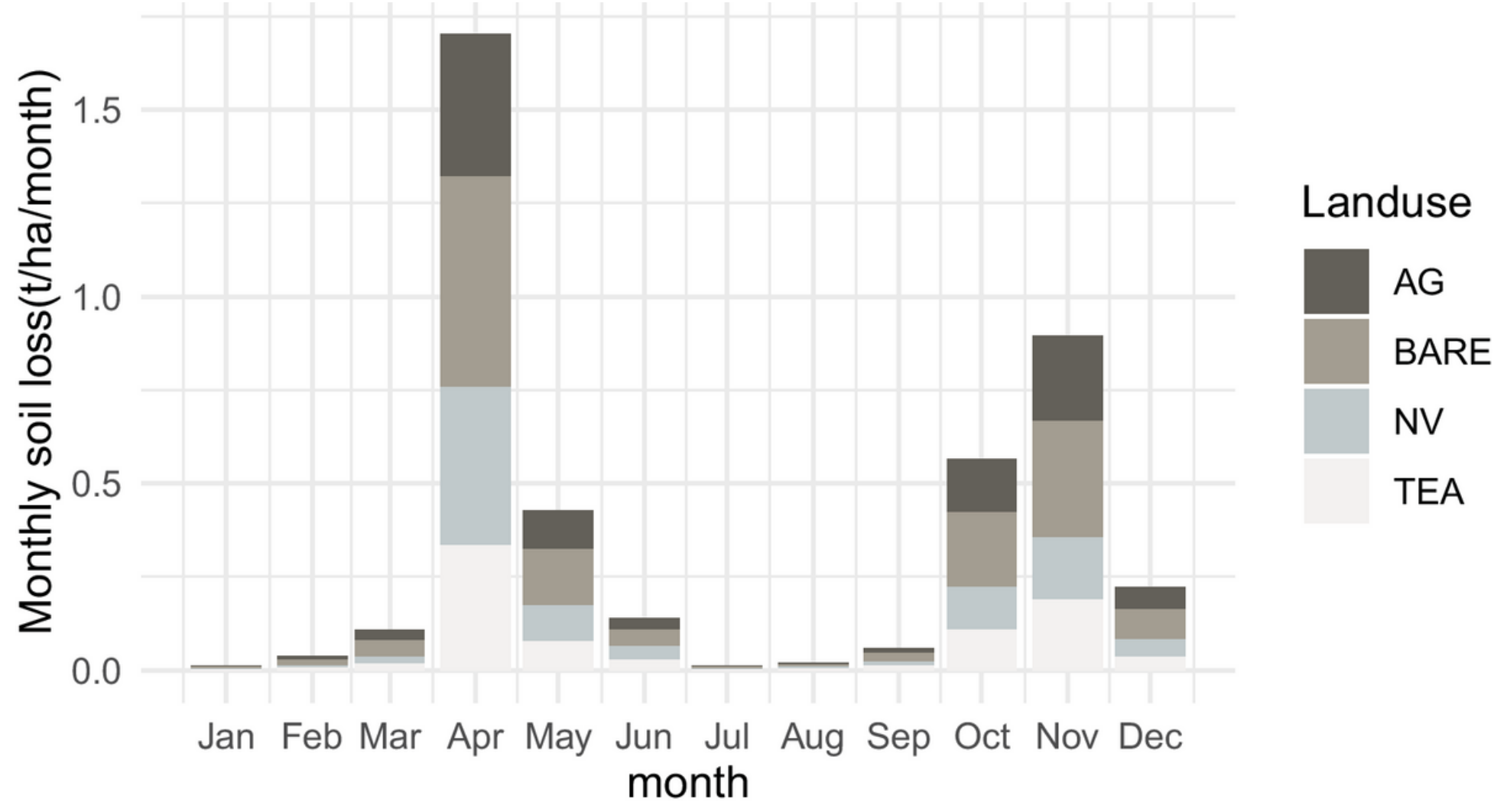

Figure 8

Soil erosion dynamics under different land use and land cover (LULC). AG- cropland, BARE- bare land, NVnatural vegetation, TEA- tea plantation 